\title{
Working of Section 153A of the Income Tax Act, 1961: Resolving the Conflict between the Literal Rule of Interpretation and Harmonious Construction
}

Srijita Jha* and Akshay Zaveri ${ }^{\dagger}$

\section{Abstract}

This article ventures into the various interpretations given by the court for the execution of Section 153A of the Income Tax Act, 1961. It has forever been a conflict as to how the particular section has to be interpreted, in order to decide whether the items of regular assessment can be added back in the proceeding under section 153A, after the finalization of assessment. This article tries to decode the mixed opinions of the court with regard to whether it is the literal rule of interpretation or the rule of harmonious construction that would apply to interpret Section 153A. This issue has been dealt with by the authors by analysing the various tools of interpretation of statutes like Literal Rule of Interpretation, reading down of statute as a whole, Rule of Harmonious Construction of statute etc. and their application in various cases based on judicial dicta of the court of law. The authors, based on thorough analysis of Section 153A, based on the language of the provision and the interpretations attached to it by the Judiciary, have tried to resolve the conflict between the Literal rule of interpretation and harmonious construction.

* Gujarat National Law University, Gujarat, India; srijita.jha@gmail.com

+ Gujarat National Law University, Gujarat, India; akshayzvr8@gmail.com 
Keywords: Casus Omissus, Harmonious Construction, Incriminating material, Literal Rule of interpretation, Undisclosed Income

\section{Introduction}

This research paper mainly discusses the various interpretations given by the Courts with respect to Section $153 \mathrm{~A}^{1}$ of the Income Tax Act,1961 (hereinafter referred to as Act) which mainly addresses the issue of items of regular assessments being added back in proceedings under Section 153A. Further, it talks about the importance of a notice being issued to the assessee when any further assessments are to be made, either with the purpose of adding items after finalizing the assessment or otherwise. This undertaking would discuss cases where in the Literal Rule of Interpretation is followed. When it comes to deciding this issue on the basis of the primary rule of interpretation, the intention has to

1 §153A, Income Tax Act, No. 43, Acts of Parliament, 1961 - "(1) Notwithstanding anything contained in Section 139, Section 147, Section 148, Section 149, Section 151 and Section 153, in the case of a person where a search is initiated under Section 132 or books of account, other documents or any assets are requisitioned under Section 132A after the 31st day of May, 2003, the Assessing Officer shall -

(a) issue notice to such person requiring him to furnish within such period, as may be specified in the notice, the return of income in respect of each assessment year falling within six assessment years referred to in clause (b), in the prescribed form and verified in the prescribed manner and setting forth such other particulars as may be prescribed and the provisions of this Act shall, so far as may be, apply accordingly as if such return were a return required to be furnished under section 139;

(b) assess or reassess the total income of six assessment years immediately preceding the assessment year relevant to the previous year in which such search is conducted or requisition is made:

Provided that the Assessing Officer shall assess or reassess the total income in respect of each assessment year falling within such six assessment years:

Provided further that assessment or reassessment, if any, relating to any assessment year falling within the period of six assessment years referred to in this sub-section pending on the date of initiation of the search under Section 132 or making of requisition under Section 132A, as the case may be, shall abate." 
be found from the words used by legislature itself and that the Court should not supply casus omissus except in cases of clear necessity and when reason for it is found in the four corners of the statute itself. The Court should not interpret the statute so as to create casus omissus when there is none. On the other hand, there are often arguments that the provisions of Section 153A should be construed harmoniously since literal construction leads to anomalous results. Assessment under Section 153A takes place in case of search proceedings and hence assessment can only be opened when search yields some incriminating materials while also giving the benefit of doubt, if any to the assessee.

This article, through various cases and instances, makes an effort to unravel this issue, which has forever been disconcerting, when it comes to implementation of this area of law.

\section{Working of Section 153A}

The Assessing Officer is legally allowed to examine the earlier assessment, even if assessment has been conducted as per Section $143(3)^{2}$ of the Income Tax Act,1961. As a matter of rule and practice, search under Section 132 is always preceded by a proper satisfaction note, recording the facts and circumstances and making out of a prima facie case justifying the conduct of a search action. When it is so, non-recovery of incriminating material cannot make the satisfaction note non-existent. Even if incriminating material is not found, facts and circumstances narrated in the satisfaction note would still require examination and consideration later on in reference to various disclosures made by the assessee in the return of income. Clearly, assessment in Section 153A or in Section 153C, the requirement of incriminating material is nothing short of keeping oneself busy with the supposed intention. When the Section is not ambiguous, it cannot be assumed that Section 153A requires incriminating material to be present before an addition is made, as any attempt to assume so, will amount to reframing the legislation. ${ }^{3}$. In State of Kerala v. Mathai Verghese 4 it has been 
observed that the Courts cannot reframe the legislation for the very good reasons that it has no power to legislate.

The Hon'ble Supreme Court in the case of Prakash Nath Khanna $v$. CIT ${ }^{5}$ has held that:

"the first and foremost rule of construction is that the
intention has to be found from the words used by the
legislature itself. The Courts interpret the law and do not
legislate the law. If a provision has been misused or is
absurd, it is for the legislature to amend, modify, repeal, if
deemed necessary."

Thus, the provisions should be read as a whole and as they exist, and there is no necessity of reading them down or providing casus omissus. Where the search is conducted, there is a mandate on the Assessing Officer (A.O) to issue notice calling for return of all six assessment years preceding the current assessment year. Thereafter, the first proviso casts a duty on him to assess or reassess the total income in respect of each assessment year. In this respect he has no choice but to make six assessments. In order to obviate a necessity of making two assessments in respect of the year for which proceedings are pending, the second proviso provides that pending assessments shall abate, which means that only one assessment under Section 153A shall be made in respect of assessments which have abated because of this provision. Both the first and second proviso direct the A.O to assess total income, which has to be computed in accordance with Section 5 of the Act which talks about scope of total income, therefore, in respect of all the assessments, the A.O has to make an assessment or reassessment of the total income and in doing so, there is no fetter on his powers i.e., the A.O is not restricted to the consideration of only incriminating materials or undisclosed valuables. The provisions of Chapter XIV B of the Act caused excessive litigation and therefore the scheme of search assessments has been modified. In the case of ShankerNarain Construction Co. EOrs. v. State of Karnataka \& Anr', the Hon'ble Karnataka High Court held that:

${ }^{5}$ Prakash Nath Khanna v. C.I.T., (2004) 266 I.T.R. 1.

6 Shanker Narain Construction Co. \&Ors. v. State of Karnataka \&Anr, (2004) 276 I.T.R. 56. 
"nothing is to be added and nothing is to be taken away from the statute unless there are adequate grounds for doing so."

The introduction of provisions of Section 153A was to avoid litigation, which proliferated on the issue of 'undisclosed income'.7 The avowed purpose of bringing new provisions will be forfeited and the litigation will proliferate on the question as to what constitutes incriminating materials with respect to such assessments, if the same controversy is raised under the new provision as well, by arguing that no reassessment can be made in respect of completed assessment, as no incriminating material is found. The A.O can look into all matters that are necessary for him to compute the total income for all the six assessment years. Coming to the apprehension, one may assume that some additions which were made in the original assessment and deleted by the higher forum may be made in reassessment under Section 153A. However, it may be stated that such an apprehension is unfounded and the A.O under section 153A will have to follow the decision of the higher forum as a matter of judicial discipline.

\section{1 Harmonious Construction of the taxing statute v. Literal Interpretation of Section 153A}

Often there are arguments stating that language is an imperfect instrument for the expression of human intention and therefore intention of legislature has to be relied upon. ${ }^{8}$ It is a settled rule that where the literal interpretation of a statutory provision leads to a manifestly unjust result contrary to intention of legislature, the Court might modify the language used by the legislature so as to achieve the intention of the legislature and produce a rational and congruent construction. ${ }^{9}$ The provisions of the statute have to be read harmoniously in case of obscurity, ambiguity or lack of harmony created by the language of a provision in the statute. ${ }^{10} \mathrm{An}$

7 All Cargo Global Logistics Ltd v. Deputy Commissioner of Income-tax, (4212) I.T.A.T. Mumbai (1409).

8 K.P. Varghese v. ITO, A.I.R. 1981 S.C. 1922.

${ }_{9}$ South India Steel Rolling Mills, Madras vs. Commissioner of Income Tax, Madras, (1997) 9 S.C.C. 728.

10 Ashok Kumar Thakur v. UOI, (2008) 6 S.C.C. 1. 
attempt must always be made so to reconcile the relevant provisions as to advance the remedy intended by the statute. ${ }^{11}$ One provision should be construed with reference to the other provision to make the provision consistent with the object sought to be achieved. ${ }^{12}$ The words of Learned Hand J. as quoted by the Supreme Court in Union of India v. Filip Tiago De Gama13, aptly describe the above propositions:

"Statutes should be construed, not as theorems of Euclid, but with some imagination of the purposes which lie behind them."

The first proviso to Section 153A reiterates the words of Section 153A (1) (b) that the total income of previous six years needs to be assessed or reassessed immediately preceding from the assessment year relevant to previous year in which search is conducted or requisition is made. On a literal interpretation of the given provisions, it may be concluded that the provision demands assessment or reassessment for all the six years and hence additions may be made even in cases of completed assessments as per the first proviso. However, applying the doctrine of Harmonious Construction, the first proviso should be read in harmony with the second proviso under Section 153A. The second proviso expressly states that only the proceedings pending at the time of search or seizure would abate, which led to the conclusion that completed assessments do not abate and hence stand as it is. A harmonious construction of the entire provision would lead to the conclusion that the word 'assess' has been used in the context of abated proceedings and reassess has been used for completed assessment proceedings. This would not abate as they are not pending on the date of initiation of the search, or making of requisition. This would also necessarily support the interpretation that for the completed assessments, the same can be tinkered, only based on the incriminating material found during the course of search or requisition of documents. ${ }^{14}$

11 SirajulHaq Khan v. Sunni Central Board of Waqf, A.I.R. 1959 S.C. 198.

12 Anwar Hasan Khan v. Mohd. Shafi and Ors. (2001) 8 S.C.C. 540.

13 Union of India v. Filip Tiago De Gama, (1990) 1 S.C.C. 277.

14 Jai Steel (India) v. Asst. Commissioner of Income, [2013] 219 Taxman 223 (Raj). 
Sections 153A, 153B, 153C and 153D were introduced later by the legislature, to specifically address the issue of assessment, in cases of search and seizure after 31 $1^{\text {st }}$ March 2003.15 Therefore, Section $153 \mathrm{~A}$ is intricately linked with Section 132 and 132A of the Act. ${ }^{16}$ The logical corollary which follows is that, though assessment has to be made of total income in the period of six years preceding the previous year, but any additions or changes in completed assessments could only be made on finding of any material during the search. Therefore, the assessee respectfully submits that according to the dominant object doctrine ${ }^{17}$, the provision of Section 153A, 153B, 153C and 153D were framed to effect assessment in case of search or seizure. In such case, if additions are made without any undisclosed or escaped income being found, then it will only amount to change of opinion of the A.O. which will not be in congruity with the intention of the Legislature.

However, all these arguments and interpretations of the written law disregard the primary rule of interpretation which is that the intention has to be found from the words used by legislature itself. 18 The rules of interpretation other than the literal rule would come into play only if there is any doubt with regard to the express language used or if the plain meaning would lead to an absurdity. ${ }^{19}$ The statutory language is clear and in its literal interpretation, it does not give any absurd and anomalous results. The Court should not supply Casus Omissus except in cases of clear necessity and when reason for it is found in the four corners of the statute itself. ${ }^{20}$ The court should not so interpret the statute as to create Casus Omissus when there is really none. ${ }^{21}$

15 C.I.T. v.M/s. PurtiSakharKarkhana Mahal, (2013) 153 T.T.J. (Nag) 12.

16 Jai Steel, supra note 8.

17 C.I.T. v. Surat Art Silk Cloth Manufacturers Association, [1980] 121 I.T.R. 1 (S.C.).

18 PrakashNathKhanna v. C.I.T., (2004) 266 I.T.R. 1 (S.C.).

19 Pandian Chemicals Ltd. v. C.I.T., (2003) 5 S.C.C. 590.

20PadmaSundaraRao (Deceased) v. State of Tamil Nadu, (2002) 255 I.T.R. 147 (S.C.).

${ }^{21}$ Shankaranarayana Construction Co. and Ors.v. State of Karnataka and Anr. (2004) 276 I.T.R. 56 (Kar.). 
In Section 153A of the Act, the first proviso clearly states that the Assessing Officer shall assess or reassess the "total income" in respect of each assessment year, falling within such six assessment years. This total income has to be computed as per Section $5^{22}$ of the Act. Assessing authority can take note of the income disclosed in the earlier return, any undisclosed income found during search or and also any other income which is not disclosed in the earlier return or which is not unearthed during the search, in order to find out what is the total income. ${ }^{23}$ There can be only one assessment order in respect of each of the six assessment years, in which both the disclosed and the undisclosed income would be brought to tax. ${ }^{24}$ Therefore, it is clear that even if an assessment order is passed under Section 143(1) or 143(3) of the Act, the Assessing Officer is empowered to reopen those proceedings and reassess the total income taking note of the undisclosed income, if any, unearthed during the search. ${ }^{25}$ The purpose of second proviso is to prevent multiplicity of proceedings and to ensure that there are no two conflicting authorities on the same point. ${ }^{26}$ There is no disconnecting between the first and second proviso. The words assess and reassess used in the provision signify two things. The word assessment is used in context of proceedings, which shall abate because of second proviso, and reassessment has been used in context of the completed assessment proceedings, which would not abate as they are not pending on the date of initiation of the search or making of requisition ${ }^{27}$.

\section{II.2 Reading down of the provision found Ultra-Vires}

No additions can be made in cases of completed and finalized assessments. This is because an assessment once made is final and it is not open to the department to go on making fresh computation

${ }^{22} \S 5$, Income Tax Act, No. 43, Acts of Parliament, 1961.

${ }^{23}$ Canara Housing Development Company v. D.C.I.T., MANU/ KA/3491/2014.

${ }^{24}$ C.I.T. v. Anil Kumar Bhatia, (2012) 211 Taxman 453 (Delhi).

${ }^{25}$ supra note 23.

${ }^{26}$ Memorandum Explaining Finance Act, 2003, available at http:/ / www.indiabudget.nic.in/ub2003- 04/mem/mem1.pdf.

${ }^{27}$ supra note12. 
orders to the end of the time. ${ }^{28}$ The same limitations can be read into provisions of Section 153A and it may be concluded that finality of concluded assessments cannot be disturbed.29 The same has been reiterated by various tribunals. ${ }^{30}$ Section $153 \mathrm{~A}$ envisages assessment of total income and not only that of undisclosed income. ${ }^{31}$ It was further made clear by the Allahabad High Court that only the pending assessments and not the completed assessments, abate on initiation of proceedings under Section 153A. ${ }^{32}$ Therefore, assessment as envisaged by the second proviso would be held in cases of abated proceedings while reassessment can only be done in cases of completed assessments where incriminating material is found. 33 Thus finding of incriminating material is a prerequisite to tinker with the finalized or completed assessments. ${ }^{34}$. In the case of CIT $v$. Lancy Constructions ${ }^{35}$, the High Court of Karnataka held that "assessment cannot be reopened on the basis of a search where no incriminating evidence is found and merely on the basis of further investigation of books of accounts as that would amount to the Revenue getting a second opportunity which is not permissible in law."

Under Section 153A of the Income Tax Act 1961, on satisfaction of certain conditions, the Assessing Officer is under the obligation to issue the notice to the person requiring him to furnish the return of income of six years immediately preceding the year of search, where a search or requisition is initiated after 31.05.2003.

The word used here is "shall" and thus the Assessing Officer is under a complete obligation to assess or reassess the real income of those six years on the basic of the material found in search. In the case of All Cargo Global Logistics Ltd \& Others v. Deputy Commissioner

\footnotetext{
28 I.T.O. v. Habibullah (S.K), [1962] 44 I.T.R. 809 (S.C.).

29 C.I.T. v. Continental Warehousing Corporation (NhavaSheva) Ltd., [2015] 374 I.T.R. 645 (Bom).

30 A.C.I.T. v. Mrs. Uttara S. Shorewala, [2011] 48 S.O.T. 6 (Mum).

31 C.I.T. v. Anil Kumar Bhatia, [2013] 352 I.T.R. 493(Delhi).

32 C.I.T. v. Shaila Aggarwal, [2012] 346 I.T.R. 130 (All).

33 All Cargo Global Logistics Ltd. v. D.C.I.T., [2012] 181 I.T.R. 106 (Mum).

${ }^{34}$ C.I.T. v. Kabul Chawla, [2015] 61 taxmann.com 412 (Delhi).

35 C.I.T. v. Lancy Constructions, I.T.A. 528/2014.
} 
of Income Tax, Mumbaij6 it was held that in other cases, in addition to the income that has already been assessed, the assessment under Section 153A will be made on the basis of incriminating material, which in the context of relevant provisions means-

(i) books of account, other documents, found in the course of search but not produced in the course of original assessment, and

(ii) undisclosed income or property discovered in the course of search.

The Income Tax Appellate Tribunal, Delhi Bench in the case of Sanjay Aggarwal v. DCIT ${ }^{37}$, after reiterating the decision of Hon'ble Delhi High Court in the case of Anil Kumar Bhatia ${ }^{38}$, and ITAT Special Bench in case of All Cargo (supra), has held: "We, therefore, hold in principle that no addition can be made for any assessment year $\mathrm{u} / \mathrm{s}$. 153A, the assessment for which is not pending on the date of search, unless any incriminating material is found in the course of search."

The Kolkata Bench of ITAT in LMJ International v. Dy. CIT, 39 while discussing the nature of additions held that, where nothing incriminating is found in the course of the search relating to any assessment years, the assessments for such years cannot be disturbed. The Ahmedabad Bench of the ITAT in the case of Meghmani Organics Ltd v. Dy CIT ${ }^{40}$, has observed that:

"The power under Section 153A of the Act should, therefore, be with reference to assessment or reassessment of pending assessment or qua the materials found during the search. Since admittedly nothing was found during the search to suggest that any income has escaped assessment, the $A O$ does not have any jurisdiction for framing assessment under Section 153A of the Act."

${ }^{36}$ All Cargo Global Logistics Ltd \& Others v. Deputy Commissioner of Income Tax,Mumbai, 147 T.T.J. 513.

37Sanjay Aggarwal v. D.C.I.T., I.T.A. No.3184/Del/2013.

${ }^{38}$ Anil Kumar Bhatia, 352 I.T.R. 493 (Del).

39LMJ International v. Dy. C.I.T., (2008) 119 T.T.J. (Kol.) 214.

${ }^{40}$ Meghmani Organics Ltd v. Dy. C.I.T.(2010) 129 T.T.J. (Ahd.) 255. 
In CIT v. Kabul Chawlat, it was held that where on the date the search assessment stands completed and there is no incriminating material, no additions can be made on income already assessed. In Guruprerna Enterprises v. Asst. CIT ${ }^{42}$, it was held that under Section $153 \mathrm{~A}$, the issues decided in the assessment cannot be reconsidered and re-adjudicated, unless there is some fresh material found during the course of the search in relation to such points.

Also in the case of Gurinder Singh Bawa v. Dy CIT43, it was held that where search under Section 153A is being carried out by the Assessing Officer and wherein all the assessments pertaining to six years immediately preceding to the assessment years were complete, the Assessing Officer cannot make an addition in those completed assessments, unless there is any incriminating material recovered during the search.

On the other hand the principle of reading down should be used only in cases where plain and literal meaning of the provision confers arbitrary, uncanalised or unbridled power. In other words, the question of reading down comes in, if it is found that the provisions are ultra-vires. ${ }^{44}$ Section $153 \mathrm{~A}$ was held to be intra-vires in Saraya Industries Ltd. v. Union of India ${ }^{45}$ due to the fact that notice is required to be issued which clearly postulates that the principles of natural justice are incorporated in the provision. In the case of Union of Indian and Another v. DeokiNandan Aggarwal it was held by the Hon'ble Supreme Court that:

"There is nothing in the language of the provisions, which
would indicate that the assessment is restricted to
incriminating material or the basis of the assessment
would be, that which is discovered during the search.
When the legislature has provided unfettered power to the
Assessing Officer then the court cannot impose fetters.

${ }^{41}$ CIT v. Kabul Chawla, I.T.A. No. 707/2014/ Delhi H.C.

${ }^{42}$ Guruprerna Enterprises v. Asst. C.I.T., (2014) 38 D.T.R. 225.

${ }^{43}$ Gurinder Singh Bawa v. Dy. C.I.T., (2013) 149 I.T.R. 29.

${ }^{44}$ Electronics Corporation of India and Others. v. Secretary Appellant Department, Government of Andhra Pradesh and others, (1999) 4 S.C.C. 258; K.G. Ashok \& Others v. Kerala Public Service Commission \& Others, (2001) 5 S.C.C. 419.

45Saraya Industries Ltd v. Union of India, (2008) 216 C.T.R. Del 257. 
The court cannot add the words to a statute or read what is not expressly provided." 46

The wisdom of the legislature should be respected and it could not be presumed that it passed an invalid legislation. In many cases, the various courts have interpreted Section 153A with fetters and with qualifications. This is wholly unnecessary and against the power of the courts such as in Saf Yeast Co. Pvt. Ltd, Mumbai v. Department Of Income Tax ${ }^{47}$, where it was held that the Assessing Officer under Section 153A has been entrusted with the duty of bringing to tax the total income of an assessee whose case is covered by Section 153A, by even making reassessments without any fetters, if need be. In case where there are two interpretations possible, the one validating the statute should be adopted. For this purpose, the court may have to give restrictive or expansive meaning keeping in view the nature of legislation. ${ }^{48}$

Provisions in Sections 153A-153C were introduced in place of the provisions contained in Chapter XIV B. The earlier provisions led to parallel proceedings, being regular assessment proceedings and computation of undisclosed income ${ }^{49}$. This resulted in excessive litigation and thus the scheme was modified. Therefore, in the new provisions, Assessing Officer is given the power to assess the total income, intention being to avoid proceedings which proliferated on the issue of "undisclosed income". The memorandum explaining the Finance Act does not use the word "undisclosed" anywhere while explaining the new provisions of Section 153A to 153C. If the same controversy is raised under the new provision, by arguing that no reassessment can be made with respect to complete assessment, where no incriminating material is found, the avowed purpose of bringing new provisions will be forfeited and the litigation will proliferate on the question as to what constitutes incriminating material with respect to such assessments.

46 Union of Indian and Another v. DeokiNandanAggarwal, 1992 Supp. (1) S.C.C. 323.

47Saf Yeast Co. Pvt. Ltd, Mumbai v. Department of Income Tax, I.T.A. No. 5182/Mum/2007.

${ }^{48}$ Calcutta Gujrati Education Society v. Calcutta Municipal Corporation and Others, (2003) 10 S.C.C. 533.

${ }^{49}$ supra note 48 . 
So it would be safe to say that even if the legislation produces some unjust results, it is for the legislature to amend. Court interprets and does not legislate. If provision has been misused or is absurd, it is for the legislature to amend, modify or repeal it, if deemed necessary. Legislative casus omissus cannot be supplied by judicial interpretative process. ${ }^{50}$ Computing re-assessment for all six years even if no incriminating material is found in course of search for some years does not amount to harassment etc. and even if it does so, the same has to be ignored in view of clear statutory provision. ${ }^{51}$

\section{II.3 The statute must be read as a whole}

Every clause of a Section should be construed with reference to the context and other clauses thereof so that the construction to be put on a particular provision makes a consistent enactment of the whole statue. ${ }^{52}$ Section $153 \mathrm{~A}$ should be read in context of other Sections such as Section 132, 143, 147, 148 etc.

Section 153A should be read with Section 132. It is to be noticed that the prerequisite for invoking assessment under Section 153A is search under Section 132. Once the Section is triggered, it is mandatory for the Assessing Officer to issue notices calling upon the assessee to file returns for the six assessment years prior to the year in which the search took place. ${ }^{33}$ When the assessee will file return for six years, no fetter can be imposed on assessing officer while conducting assessment. The search under Section 132 is based on "reasons to believe" and is open to challenge under Article 226. In C. Ramaiah Reddy v. Assistant Commissioner of Income $e^{54}$, it was categorically held that what could be the subject-matter of a Writ Petition under Article 226 cannot be the subject-matter of a statutory appeal under the Act. Further, they have said that the right of appeal is a right, which has to be conferred by a specific provision under the statute, when a statute does not provide for an

\footnotetext{
50 supra note 40.

51 All Cargo Global Logistics Ltd. v. D.C.I.T., (2012) 137 I.T.D. 287 (Mum).

52 supra note 42 .

${ }^{53}$ supra note2.

54 C. Ramaiah Reddy v. Assistant Commissioner of Income, (2011)244C.T.R.(Kar)126.
} 
appeal against the action under Section 132(1). The assessee not only has the right of appeal but an appeal filed against the assessment order he cannot challenge the validity of a search. Section 132 is the prerequisite for Section 153A but to restrict the scope of the additions under Section 153A because of language of Section 132 will give a very narrow interpretation to Section 153A.

If the interpretation as per the doctrine of harmonious construction is accepted, it will mean that during pendency of assessment proceedings under Section153A, separate proceedings under Section $148^{55}$ may be initiated for making assessment of escaped income, discovered otherwise, than during the course of search. It is an established proposition that once proceedings are pending under Section 153A, no parallel proceedings under Section 143(3) or Section 147 or Section 148 would lie. The second proviso was included specially to avoid multiplicity of proceedings ${ }^{56}$. There is no such proviso in Section 158B and thus separate assessment or reassessment proceedings are permitted under normal provision of the Act.

It is a settled principle of law that when reopening a case under Section 148, any income that has escaped assessment and which comes to the notice of the A.O. in the course of the reassessment proceedings can be assessed. This income is exclusive of the income that has escaped assessment for which the case has been reopened under Section 148. Limiting the scope of proceedings under Section 153A would imply putting the searched person at premium in comparison to the normal situation. This occurs as there is no apparent mechanism by which such escaped income (which was not discovered during the course of search but came to notice either in post search investigation or during investigation carried out in the assessment proceeding or any other source), can be assessed.

Perusal of Section 153A will show that it starts with a non obstante clause. This clause removes fetters imposed upon the Assessing Officer to assume jurisdiction to reopen the assessment under Section 147 and Section148. The time-limit within which notice under Section 148 can be issue, as provided in Section 149 has also

55§148, Income Tax Act, No. 43, Acts of Parliament, 1961.

${ }^{56}$ supra note54. 
been made inapplicable by the non obstante clause. ${ }^{57}$ The requirement under Section 151 and time limit prescribed under Section 153, have also been done away with, in cases covered under Section 153A. With all fetters having been pulled out, the Assessing Officer under Section 153A has been entrusted with the duty of bringing to tax, the total income of an assessee whose case is covered by Section 153A, by making reassessments without any fetters, if need be.

The ITAT has held that completed assessments will abate even if no incriminating material is found in course of search.58 Therefore it would be incorrect to hold that the items of regular assessments cannot be added back in proceedings under Section 153A and in concluded assessments under Section 143(3) or where no notice under Section 143(2) has been issued to initiate the proceeding under Section 143(3). But when the assessment has attained finality due to passage of time, it cannot be disturbed in a proceeding under Section 153A.

\section{Conclusion}

The authors conclude that under Section 153A, additions can only be made in cases of completed and finalized assessment when some incriminating material is found. Based on the rule of Literal Interpretation of the Statute and reading down the statute as a whole, it is clear that the main objective of the Legislature behind Section 153A of the Income Tax Act, 1961 is to entrust the Assessing Officer with the duty of bringing to tax the total income of an assessee, whose case is covered under Section 153A. This is achieved by making reassessments without any fetters and thereby also includes the reassessment of the completed assessments even if no incriminating material has been found during the course of search or requisition of documents. Further, limiting the scope of proceedings under Section 153A would imply putting the searched person at premium, in comparison to the normal situation, as there

\footnotetext{
${ }^{57}$ supra note 45.

${ }^{58}$ RajatTradecom India (P) Ltd. v. Dy. C.I.T, 120 I.T.D. 48 (Indore), Shivnath Rai Harnarain (India) Ltd. v. D.C.I.T., 117 I.T.J. 480; ShyamLata Kaushik v. A.C.I.T., 114 I.T.D. 305.
} 
is no mechanism by which such escaped income can be assessed. Thus, going by the intent of the legislature the authors are of the view that Section 153A of the Act includes within its scope the reassessment of even the completed assessments, even if no incriminating material has been found during the course of search. 